\title{
Fuel tourism in border regions: The case of Switzerland
}

\author{
Silvia BANFI * * \\ Massimo FIUPPINI* \\ Lester CHUNTA \\ * Swiss Federal Institute of Technology, Centre for Energy Policy and Economics \\ (CEPE) and \\ Università della Svizzera italiana, Istituto di microeconomia e economia Pubblica \\ ^Surrey Energy Economics Centre (SEEC), Department of Economics, University of \\ Surrey, UK
}

\begin{abstract}
This paper explores the issue of 'fuel tourism' in Switzerland. For the period 1985 to 1987, a panel data model for the border regions of Switzerland, (Italy, France, and Germany) is estimated. The results show a significant impact of the gasoline price differential on demand, suggesting that a decrease of $10 \%$ in the Swiss gasoline price leads to a reduction in demand in the border areas of nearly $171 / 2 \%$. It is shown that fuel tourism accounted for about $9 \%$ of overall gasoline sales in the three regions during the period 1985 to 1997 and that the recently proposed Swiss $\mathrm{CO}_{2}$-tax might, given current conditions, eliminate net fuel tourism.
\end{abstract}

Keywords: Fuel Tourism; Gasoline price differentials; Panel data estimation

Classification code: H2O (Taxation, Subsidies, and Revenue; General); Q41(Energy; Demand and Supply)

Acknowledgements

We are grateful for comments received following the presentation of an earlier draft of this paper at the Annual Congress of the Swiss Society of Economics and Statistics, March 2003, Bern, Switzerland the British Institute of Energy Economics (BIEE) Conference, Oxford, UK September 2003 and the Annual Conference of the European Association of Environmental and Resource Economics, June 2004, Budapest, Hungary. We also would like to thank INFRAS, Zurich and Berne, for the data provision and two anonymous referees for their very helpful comments on an earlier draft. The authors are, of course, responsible for all errors and omissions.

\footnotetext{
* Corresponding Author:

Silvia Banfi

Swiss Federal Institute of Technology

Centrefor Energy Policy and Economics (CEPE)

ZUE

$\mathrm{CH}$ - 8092 Zürich

Tel: +4116320655

Fax: +4116321050

e-mail sbanfi@ethz.ch
} 


\section{Introduction}

The gasoline price differential existing across the border between Switzerland and its neighbouring countries (the gasoline price in Switzerland is generally lower than in the neighbouring countries) has encouraged the phenomenon of fuel tourism to develop. People living in the border regions of Italy, France and Germany have had an incentive to buy gasoline in Switzerland for several years. Based on the methods and results presented in the literature of cross-border purchasing, this study focuses on the cross border behaviour of foreign car drivers choosing to fill their vehicle tanks in Switzerland. The fiscal policy of the Swiss government in relation to fuel taxation differs from the fiscal policies of its neighbouring countries, Germany, Italy, and France with both VAT and general taxes on leaded and unleaded gasoline and automotive diesel ${ }^{2}$ somewhat lower in Switzerland. This results in lower gasoline prices in Switzerland as is illustrated in Figure 1 for 1997, which gives similar price differentials to those at the beginning of $2005^{3}$ However, more recently the Swiss government has proposed to introduce a $\mathrm{CO}_{2}$-tax of 20 Swiss Cents per litre of Gasoline which, if implemented, would go some way to reducing the cross border differential. ${ }^{4}$ This paper therefore attempts to estimate the extent of the crossborder fuelling ('fuel tourism') and also consider the possible effects of the proposed $\mathrm{CO}_{2}$-tax.

\section{\{Figure labout here\}}

\footnotetext{
${ }^{1}$ Swiss Federal Office of Energy, 2001, http:// www.energieschweiz.ch/imperia/md/content/energiepolitik/3.pdf

${ }^{2}$ IEA (1999)

${ }^{3}$ On average, the price difference between Switzerland and the neighbouring countries (France, Italy and Germany) amounts to around 30 Swiss Cents (February 2005, seehttp://www.autosieger.de)

${ }^{4}$ Swiss Federal Law on the Reduction of CO2-Emissions (Bundesgesetz vom 8. Oktober 1999 zur Reduktion der CO2-Emissionen, CO2-Gesetz)
} 
Since fuel is an almost homogeneous product, it is expected that car drivers react rationally to price differences across gas stations. Therefore, the conspicuous price differentials between Switzerland and its neighbouring countries should have led to a significant amount of fuel tourism in the Swiss border regions. Actually, people living in the bordering regions of Italy, France and Germany had, for several years, an incentive to buy gasoline in Switzerland. This phenomenon has some positive sideeffects for the Swiss economy, given the increased employment and fiscal revenues, whereas the neighbouring countries experienced lower fiscal revenues and a decrease in the employment in the gasoline distribution sector. Because of the very high price differentials (at least in some years), these repercussions were particularly important in the Italian border regions. The negative impact on the government revenues actually induced the North-Italian province of Lombardy in 2000 to adopt measures to try and prevent fuel tourism (in Italy, similar measures have dready been adopted in the regions neighbouring Slovenia). For instance, the inhabitants in the regions near to the border can take advantage of significant tax rebates at the fuel stations. The reaction to the price decrease was very important and suggests that car drivers react rationally to a price differential; six months after the introduction of the special tax rates at the Italian fuel stations, the fuel demand in the Swiss border regions had decreased by 20 to $40 \%{ }^{5}$ On the other side, fuel stations in Italy have realised important increases in sales. ${ }^{6}$

\footnotetext{
${ }^{5}$ Information of „Bundesverband freier Tankstellen e. V.“ (Association of the independent gas stations) www.bft.de/ bft/aktuell/dittert.htm; Credit Suisse, II Ticino e le Regioni dell'Italia del Nord Struttura e prospettive economiche, Economic Research - Analisi regionali, October 2000.

${ }^{6}$ Unfortunately, the data set used for our analysis does not include the years after the Italian tax rebates for fuel stations near the Swiss border. However, price changes during the observation period were important enough to allow estimations of their impact on demand.
} 
The high density of gasoline stations in the border regions is arguably an indicator of the importance of fuel tourism in these areas. In particular, for 1997 in the border region to Italy there were 5.6 gasoline stations per $10^{\prime} 000$ vehicles, which was much higher than the Swiss average of 3.1 stations. At the same time, the population density of the Canton Ticino, at around 109 inhabitants per $\mathrm{km}^{2}$, was lower than the Swiss average of $1 / 2$ inhabitants per $\mathrm{km}^{2}$. In the border region of the Canton BaselCity the fuel station density was 6.1per 10 '000 vehicles, significantly above the Swiss average. Moreover, this region is characterised by a high population density of over 5'000 inhabitants per $\mathrm{km}^{2}$ in 1997. Furthermore, the Cantons Ticino and Basel-City both have a very high number of commuters daily crossing their borders (on average, between $27^{\prime} 000$ and 30 '000 for the year 1997). ${ }^{7}$ Consequently, this has led to the high density of gasolinestations in these areas.

The aim of the paper is to identify the impact of price differentials on cross border gasoline fuelling behaviour. This insight is interesting for the fiscal policy of a country and may imply a spatially differentiated fiscal policy, with a spatial graduation of fuel taxes, which should prevent car drivers from fuel-tanking trips abroad. The impact of fuel tourism in the border regions of Switzerland with Italy, France, and Germany is analysed by estimating a panel data model over the period 1985 to 1997. This produces an estimate of the effect of the differential price on the impact of fuel tourism. Moreover, the model is used to estimate the overall effect of the fuel tourism in the three regions over the estimation period and to indicate the possible effects of the proposed Swiss $\mathrm{CO}_{2}$-tax. The next section of the paper therefore discusses previous work on cross-border price effects and Swiss gasoline

\footnotetext{
${ }^{7}$ This represents around 33\% of all commuters coming to Switzerland (Zentrales Ausländerregister, 3112000).
} 
demand. Section 3 describes the data, and section 4 introduces the model, utilised in the empirical estimation. In section 5 the estimation results are presented and interpreted with a brief summaryand conclusion presented in section 6.

\section{Background}

\section{Cross-border effects of price-differentials}

There exists a broad literature analysing the cross-border effects of price differences. These differentials are usually given by country specific fiscal policies, which can be observed, particularly for alcohol, cigarettes, and gasoline. Coats (1995) estimates the effect of state cigarette taxes on the cross-border sales of cigarettes for 48 contiguous states of the United States and the district of Columbia during the period that the states taxed the cigarettes, showing the extent to which inhabitants of the border regions realise the arbitrage opportunities. Saba et al. (1995) also investigate the impact of border crossing on cigarette sales among similar US states using a micro-analytic model with a nonlinear econometric specification, concluding that that border crossing is a significant determinant of sales in at least some states. They also conclude that the cross-border effects typically result in elasticities greater than those obtained from a 'naive' model that imposes the restriction of no border crossing. 
Beard et al. (1997) apply a similar micro-analytic model to Saba et al. (1995) to crossborder consumption of Beer and Liquor consumption in the United States, resulting in similar conclusions that despite cross border activity usually being small, bordercrossing is a significant determinant of alcohol demand in at least some states. Garrett and Marsh (2002) analyse cross-border lottery shopping behaviour for 105 Kansas counties (40 of them are border counties) and show that these revenues cannot be considered a reliable and stable revenue source because of the importance of cross-border lottery competition.

Di Matteo and Di Matteo (1996) analyse the cross-border shopping behaviour between Canada and the USA using per apita same day automobile trips from Canada to the United States and expenditure. They show that income, the exchange rate, gasoline prices and the Goods and Services Tax as well as seasonal factors can explain over $90 \%$ of the variation in same day cross-border trips. Also Merrifield and Storer (1999) analysed the importance of exchange rates on cross-border shopping between Canada and the United States (Whatcom County). The volatility of the exchange rates for the period 1988-1997 was pronounced and affected considerably the structure of the gasoline retailers in both countries raising the question of the regional costs of exchange ratefluctuations.

In addition to the differences in the fiscal burden observed between the United States and Canada, Lilley III and De Franco (1996) also observe differences between different US States, by studying the impact of such tax-driven price differentials on cross-border consumer purchasing. across US States. Their analysis suggests that 
tax differentials can have a significant impact on the level of welfare and job creation between neighbouring areas.

One study that considers cross-border effects of gasoline price differentials between European countries is Rietveld et al. (2001). They focused on the consequences of a spatial graduation of fuel taxes in terms of shifts in fuelling patterns, tax receipts, and mileage. Their analysis demonstrates that the propensity of Dutch households to fill their cars in Germany is high; given a price differential of $5 €$-cents, approximately $30 \%$ of the Dutch car owners living at the border would fuel in Germany. Another study, Michaelis (2003), focuses on the potential effects of price differentials between Germany and its neighbouring countries using a 'cost-benefit analysis'. All travel costs (including time costs) are summed and compared to the cost savings due to fuel price differentials, and via scenarios calculates the border area which is potentially affected by fuel tourism.

\section{Swiss Gasoline Demand}

There are two papers that we are aware of that have considered gasoline demand within Switzerland. Although they do not consider cross border fuelling, it is interesting to look at these and compare the results. Wasserfallen and Güntensperger (1988), using data for the period 1962-1985 found price elasticities of gasoline consumption of between -0.3 and -0.45 in the short run and 0.7 in the long run. Whereas, Schleiniger (1995), using an error correction model over the period 1967 to 1994 found a significant short run price elasticity of -0.24 for Swiss gasoline demand. Schleiniger emphasises that at least part of this response may be due to the arbitrage activities across the border, although the data does not allow the cross 
border effects to be isolated. However, the results from the cointegrating regression suggest that there is no long run price response. It can be expected that the price elasticity for gasoline in the border region will be higher than that for the overall countries given any price change will affect not only the domestic demand but also the demand of foreign buyers. This hypothesis will be tested with the data on fuel demand of the Swiss border regions.

\section{Model}

The household demand for gasoline is generally explained using the basic framework of household production theory. ${ }^{8}$ It is assumed that the household combines purchased market goods and its time to produce the commodity providing the utility:

$U=U(S(G, C, T), X ; D, R)$

where $\mathrm{S}$ is the transport senvice, $\mathrm{G}$ is gasoline, $\mathrm{C}$ is the capital stock (car), $\mathrm{T}$ is time, $\mathrm{X}$ is a purchased composite numeraire good that directly yields a utility while $D$ and $R$ represent demographic and geographic respectively regional characteristics which determine the household's preferences. The production function assumes a time period during which the household's automobile stock is not affected by the price of gasoline.

\footnotetext{
${ }^{8}$ For a clear presentation of the household production theory, see Becker (1965), Muth (1966) and Deaton and Muellbauer (1980). See Lin et al. (1985) for an application of household production theory to gasoline demand.
} 
In this framework the household's decision can be thought of as a two-stage optimisation problem (see Deaton and Muellbauer 1980). In the first stage, the consumer minimizes the costs of producing $\mathrm{S}$, whereas in the second stage of the optimisation problem, the household maximizes its utility. As a result, the derived household demand for gasoline can be obtained as:

$G=G(P, I, C, D, R)$

and depends on the gasoline price $(P)$, household's income $(I)$, the car availability $(C)$, and the demographic (D) and spatial (R) characteristics of the household. Assuming a constant stock of vehicles, a gasoline price increase affects only the mileage of households. Of course, in the longer run, an increase in gasoline prices affects the choice of thetype of car providing an incentive to buy more fuel-efficient vehicles.

Aggregate data on gasoline consumption have been calculated using information from gasoline companies located in an area of about 5 kilometres from the border areas. We distinguish between three areas (the border to Italy, Germany, and France) of Switzerland. Fuel tourism will, depending on the prevailing economic conditions, take place many kilometres inside of Switzerland, but the effect is likely to diminish, ceteris paribus, with the most intensive activity closest to the borders such as within the 5 kilometres used in this study. Households living in the border areas are therefore confronted with the gasoline price in Switzerland and the price in the neighbouring country, but in addition gasoline demand in these regions should be influenced by per capita income in Switzerland, per capita income abroad, population, daily commuters, ${ }^{9}$ and the stock of cars. It could be argued that the analysis should focus on gasoline consumption per capita, but this is problematical 
given it is not clear within this framework what is the appropriate population denominator. Normally, when measuring consumption per capita, the area covered by the consumption is clearly the same area as where the population resides. However, here the consumption is within $5 \mathrm{~km}$ of the Swiss border regions whereas the appropriate population is within this area and the neighbouring border areas of Italy, Germany, and France. Therefore, our general model is specified with aggregate gasoline consumption as the dependent variable, with income per capita ${ }^{10}$ for both the Swiss and neighbouring areas as explanatory variables since the areas of income and population coincide. ${ }^{\text {II }}$

Although we are primarily interested in the changes in demand due to changes in the price differential between the countries, we attempt to capture two effects in our general model: firstly the substitution of other goods for gasoline as the price increases and secondly the substitution of cross-border gasoline for home country gasoline as the price ratio changes. This is achieved by including one variable for the real Swiss gasoline price and another for the relative (real) foreign and Swiss gasoline prices. ${ }^{\mathbb{2}}$ Furthermore, to allow for the ratio of prices to have a stronger impact the higher the cross border population happens to be, a cross product term (in logs) for the relative prices and relative populations is included in the general

\footnotetext{
${ }^{9}$ Daily commuters being those who travel every day to Switzerland for working purposes.

${ }^{10}$ An alternative approach would be to use total income of the region. However, this is also problematical given the different size of the regions. For the Swiss border regions we use data at the level of the Cantons although the size of the Cantons differs significantly between each other. Furthermore, the size of the foreign border regions is much larger than the size of the Swiss Cantons. Using regional income per capita alleviates this problem; consequently we assume that the income and population data are homogeneous within the areas considered.

${ }^{11}$ However, to check on the robustness of the results some experimentation was undertaken with gasoline sales divided by the Swiss population in the border areas as the explanatory variable, and the qualitative results are similar to those presented below.

${ }^{12}$ Over the estimation period the Swiss gasoline price has been below that for the foreign countries, (other than a few years for the German region) therefore the Swiss price elasticity measures the
} 
model. Therefore the most general empirical model for households' aggregate gasoline demand, based on equation (2), can be specified in the following log-linear ${ }^{13}$ form: ${ }^{14}$

$$
\begin{aligned}
& \left.\ln G_{i t}=\alpha_{0}+\alpha_{1} \ln \left(P_{\text {Swiss }}\right)_{i t}+\alpha_{2} \ln \left(\frac{P_{\text {For }}}{P_{\text {Swiss }}}\right)_{i t}+\alpha_{3}\left[\ln \left(\frac{P_{\text {For }}}{P_{\text {Swiss }}}\right)_{i t}\right]\left[\ln \frac{N_{\text {For }}}{N_{\text {Swiss }}}\right)_{i t}\right]+\alpha_{4} \ln \left(\frac{I_{\text {Swiss }}}{N_{\text {Swiss }}}\right)_{i t} \\
& +\alpha_{5} \ln \left(\frac{I_{\text {For }}}{N_{\text {For }}}\right)_{i t}+\alpha_{6} \ln \left(N_{\text {Swiss }}\right)_{i t}+\alpha_{7} \ln \left(N_{\text {For }}\right)_{i t}+\alpha_{8} \ln (\text { Comm })_{i t}+\alpha_{8} \ln (\text { Cars })_{i t}+\mu_{i t}
\end{aligned}
$$

$$
\begin{aligned}
& \text { where } \\
& \text { i }=\text { border region (13), } \\
& \mathrm{t} \quad=\text { year }(1985-1997) \text {, } \\
& \ln \quad=\text { natural logarithm, } \\
& G_{i t} \quad=\text { gasoline demand in the Swiss border area i in yeart }(5 \mathrm{~km} \text { from the } \\
& \left(P_{\text {Swiss }}\right)_{i t} \quad=\text { Real gasoline price in Switzerland border region } \mathrm{i} \text { in yeart, (CHF) } \\
& \left(P_{F o r}\right)_{i t} \quad=\text { Real gasoline price in foreign country border region adjacent to } \\
& \text { Swiss border region i in yeart, (CHF) } \\
& \left(I_{\text {Swiss }}\right)_{i t} \quad=\text { Income in the Swiss border region } \mathrm{i} \text { in yeart, } \\
& \left(I_{F o r}\right)_{i t}=\text { Income of foreign country border region adjacent to Swiss border } \\
& \text { region } \mathrm{i} \text { in yeart, } \\
& \left(N_{\text {Swiss }}\right)_{i t} \quad=\text { Population in the Swiss border area i in yeart } \\
& \left(N_{F o r}\right)_{i t} \quad=\text { Population in foreign country border region adjacent to Swiss } \\
& \text { border area i in yeart } \\
& \text { Comm }_{i t}=\text { Foreign persons coming to Switzerland every day to work (daily } \\
& \text { commuters) from foreign border region i in yeart. } \\
& \text { Cars }_{i t}=\text { Stock of cars in border region } \mathrm{i} \text { in year } \mathrm{t} \text {. }
\end{aligned}
$$

response of both Swiss consumers and the fuel tourists whereas the foreign price elasticities measure the response of the fuel tourists only.

13The log-log specification is standard in energy demand estimation and is typically favoured for its simplicity, straightforward interpretation, and limited data requirements. Moreover, Pesaran et al. (1998) find that it generally outperforms more complex specifications across a large variety of settings.

${ }^{14}$ It is possible that Swiss fuel prices near the border regions are set at higher levels than elsewhere in Switzerland by the owners/ operators of the fuel stations because of the fuel tourism. However, there are no consistent data available in order to explore this issue of spatial price discrimination issue within this study. 
Given the competitive environment of gasoline sales, it is assumed that consumers and producers are price takers. Hence prices are treated as exogenous. It is expected, that a decrease in the Swiss gasoline price (holding the foreign price constant) will lead to an increase in the demand for gasoline in the border regions, whereas a decrease in the foreign gasoline price will have the opposite effect - but a smaller magnitude as explained above. To calculate these effects the price elasticities ( $\varepsilon p_{i t}^{\text {Swiss }}$ and $\varepsilon p_{i t}^{\text {For }}$ ) are given by differentiating equation (3) as follows:

$\varepsilon p_{i t}^{\text {Swiss }}=\left(\frac{\partial \ln G}{\partial \ln P_{\text {Swiss }}}\right)_{i t}=\alpha_{1}-\alpha_{2}-\alpha_{3} \ln \left(\frac{N_{\text {For }}}{N_{\text {Swiss }}}\right)_{i t}$

For $\mathrm{i}=$ border regions (13); $\mathrm{t}=$ year (1985- 1997)

$\varepsilon p_{i t}^{F o r}=\left(\frac{\partial \ln G}{\partial \ln P_{F o r}}\right)_{i t}=\alpha_{2}+\alpha_{3}\left(\ln \frac{N_{F o r}}{N_{\text {Swiss }}}\right)_{i t}$

For $\mathrm{i}=$ border regions $(1-3) ; \mathrm{t}=$ year $(1985-1997)$

Similarly, an increase in the income is expected to have a positive impact on gasoline demand and theestimated elasticise $\left(\varepsilon I^{\text {Swiss }}\right.$ and $\left.\varepsilon I^{F o r}\right)$ are given by differentiating equation (3) as follows:

$\varepsilon I^{\text {Swiss }}=\left(\frac{\partial \ln G}{\partial \ln I_{\text {Swiss }}}\right)_{i t}=\alpha_{4}$

For $\mathrm{i}=$ border regions (13); $\mathrm{t}=$ year (1985- 1997)

$\varepsilon I^{F o r}=\left(\frac{\partial \ln G}{\partial \ln P_{F o r}}\right)_{i t}=\alpha_{5}$

For $\mathrm{i}=$ border regions (13); $\mathrm{t}=$ year (1985- 1997) 
It is also expected that population growth will have a positive effect on the demand for transport services and hence an increase in overall gasoline demand. In addition, it is likely that commuters have an important positive role in explaining the level of gasoline demand in border regions, since they regularly travel to work in Switzerland and can therefore choose the gasoline station in the country with the lowest prices without incurring additional opportunity costs. It is likely that during the observation period (1985-1997) commuters will have chosen to fill their cars in Switzerland, since the Swiss price was lower than the price in the neighbouring countries. $^{15}$ Finally it is expected that an increase in the stock of cars will have a positive effect on the demand for transport services and hence an increase in gasolinedemand.

\section{Data}

\section{Gasoline demand}

The data on gasoline consumption were collected by the "Swiss Oil Association" ("Erdölvereinigung") for the three most important fuel companies (ESSO, BP and Shell) and include the sales of around 190 fuel stations located in an area of about 5 kilometres from the border. In Switzerland, the gasoline stations of these three companies account for approximately $30 \%$ of all Swiss gasoline stations (in the year 2001these companies owned approximately 1240 gasoline stations out of a total of 4140). We assume that these three companies are representative of the gasoline

\footnotetext{
${ }^{15}$ With the exception of the four years where the German gasoline price was lower than in Switzerland.
} 
sales (in terms of sale volumes and location of gasoline stations), so that we are able to estimate the aggregate gasoline demand for the border regions. In principle, we are assuming that the total market share of these companies for total gasoline sales is constant over time. Because gasoline can be considered a homogeneous product (in terms of quality and price), households should not have a preference in buying this good in any specific gasoline station; for this reason market shares are assumed to be constant over the sample period. Therefore, assuming that the development of gasoline sales of the three companies in our sample is representative, we can estimate the impact of the price changes on demand.

The demand data distinguish between leaded and unleaded gasoline as well as diesel, although the distinction between leaded and unleaded gasoline is available only from 1991 After 1991, a rapid shift from leaded to unleaded gasoline can be observed. This discontinuity has the consequence that the sales of leaded gasoline experience a significant decrease in the period between 1985 and 1997 . On the contrary, the demand for unleaded gasoline shows an important increase. Because of this shift in the demand for the different gasoline types, the estimation uses the aggregated demand for leaded and unleaded gasoline. ${ }^{16}$ Figure 2 shows the development of gasoline sales in the three Swiss border regions considered in the analysis (the border region to Austria has not been considered in the analysis since the number of observations in the data set for gasoline stations for this border region is not large enough).

\footnotetext{
${ }^{16}$ Diesel consumption and prices are ignored in this analysis since the proportion of diesel cars in Switzerland is relatively low (less than 4\% in 1998 according to "Unione Nazionale Rappresentanti Autoveicoli Esteri" www.unrae.it/ press/CONF02/PAG066-2.htm), although it is somewhat larger in the border countries.
} 


\section{\{Figure 2 about here\}}

Figure 2 shows that since 1985 gasoline demand has increased in every border region of Switzerland. Moreover, it is interesting to note that the development wasn't smooth but was characterised, especially in the Italian and partially also in the German part of Switzerland, by phases of increasing consumption and as well as phases of decreases in quantities sold. These sudden changes in fuel demand are arguably explained by the high price differentials between countries that have induced car drivers towards cross-border fuelling. The notable decrease of the gasoline demand in the Italian border region between the years 1994 and 1995 illustrates the likely effect of the price decrease in Italy during this period. Furthermore, in 1995 the Canton Ticino introduced some more restrictive opening hours for gasoline stations near the border (for instance forbidding the selling of gasoline on Sundays) in order to protect populations from the negative impact of fuel tourism. This restriction of the opening hours of fuel stations is probably responsible for at least one part of the observed decrease in fuel purchases.

\section{Gasoline prices}

The data set contains the annual average gasoline prices for Switzerland and the neighbouring regions (the prices are collected by the border officers every month). There are some missing data for single months, which have been interpolated using the price of the previous and the following month.

Figure 3 illustrates the differences of the leaded gasoline price between Switzerland and its neighbouring countries. It is worth noting that in Italy during the 1980 s and 
at the beginning of the 1990s the prices were significantly higher than in the other countries, but since 1993 an adjustment towards the price of other countries has occurred. The differences between Swiss and German prices are smaller; and between 1985 and 1989 prices were actually lower in Germany than in Switzerland. ${ }^{1}$ Ideally a weighted average of leaded and unleaded gasoline should be used for the price variables, but appropriate 'weights' are not available for both Switzerland and the border countries. Hence, the relative leaded price is utilised. However, this is not a particular problem given it is the relative prices across the borders that is of interest and it is unlikely the relative leaded to unleaded prices would have varied significantlyacross the different countries over the period 1993to $1997 .^{18}$

\section{\{Figure 3 about here\}}

\section{Further socio-economic variables}

Other variables considered that help to explain gasoline demand in the border regions are Swiss per capita income in the border region and foreign per capita income, cross-border commuters and the stock of cars for the Swiss border regions. Table 1 gives an overview on the minimum, maximum, and median value of the variables used in the model.

\section{\{Table labout here\}}

\footnotetext{
${ }^{17}$ Figure 3 shows the gasoline prices expressed in Swiss francs. It should be noted that one part of the price fluctuation is due to the variation in the exchange rate and the Italian Lra experienced an important loss of value from 1993 to 1996. Consequently, the gasoline price for Italian commuters and tourists increased significantly over this period; and in a more moderate way, the German Marc and the French Franc decreased in value during these years.

${ }^{18}$ Furthermore, the development of different fuel type prices (unleaded, leaded and diesel) show quite similar patterns over the sample period.
} 


\section{$5 \quad$ Results}

A panel data set characterized by a relatively small number of cross-sectional units and a relatively long time period is used to estimate equation (3). Therefore traditional panel data estimation approaches (fixed and random effects models) are not appropriate. For this reason, the estimation of equation (3) was carried out using the GLS estimation procedure for pooled time-series and cross-sectional data suggested by Kmenta (1986) and Greene (2003). ${ }^{19}$

The initial estimation of the general model, equation (3) was estimated using OLS assuming homoscedastic and non-auto-correlated disturbances. However, the Lagrange Multiplier, the Likelihood Ratio and Wald statistics all rejected the hypothesis of homoscedastic disturbances. Hence corrections were made for country-wise heteroscedastic disturbances in all further estimation. An allowance was also made for common autocorrelation across all countries and country specific autocorrelation and tested using the test suggested by Greene (2002, p. E8-90). The common autocorrelation coefficient was found to be significantly different from zero at the $1 \%$ level and the countrywide autocorrelation coefficients for Germany and France were found generally found to be significantly different from zero at the $5 \%$ level at least whereas for Italy generally it was significantly different from zero at the $10 \%$ level. Moreover, the country specific autocorrelation coefficients differ somewhat. Hence corrections were also made for country-wise autocorrelation in all 
estimated equations. Therefore the estimation of the general equation (3) allowing for country specific heteroscedasticity and country specific autocorrelation is presented as Model la in Table $2^{20}$

In this, the Swiss price, relative price, weighted relative price, Swiss per capita income, and foreign per capita income variables all have the expected signs and are significantly different from zero at the $1 \%$ level, whereas all remaining variables are not significantly different from zero at the $5 \%$ level and the signs for the coefficients on the population variables are negative. ${ }^{21}$ Therefore, the population variables were dropped from the equation along with the very insignificant car stock variable, with the results presented as Model $\mathbf{l b}$ in Table 2. All remaining variables (and elasticities) have the expected signs with the Swiss price, Swiss per capita income, commuters all significantly different from zero at the $1 \%$ level, and the weighted relative price and foreign per capita income significantly different from zero at the $5 \%$ level. However, the relative price variable is not significantly different from zero and hence was dropped from the model, with the results presented as Model $\mathbf{k}$ in Table 2 . All variables (and elasticities) have the expected signs and are significantly different from zero at the $1 \%$ level and suggest that a $1 \%$ decrease in the Swiss gasoline price would, on average, increase gasoline sales in the $5 \mathrm{~km}$ border region by $175 \%$.

\footnotetext{
${ }^{19}$ For a general presentation of this econometric procedure see Greene (2003). The estimation has been performed using the econometric software "Limdep version 8".

${ }^{20}$ In preliminary modelling dummy variables for the border regions, dummies for the different years and a time variable were included. However, given their poor fit the results are not presented here. Furthermore, a dummy variable for the year 1995 for the border region to Italy was introduced (in this year, the Canton Ticino introduced more restrictive opening hours for gasoline stations near the border). However, this proved insignificant and had no discernible effect on the estimated price elasticities.
} 
In order to check the robustness of the results, one further experiment was undertaken by re-starting the modelling process with the general equation (3) but by removing the weighted price variable. Inevitably given the construction of the weighted variable, there is a high degree of co-linearity between it and the relative price variable (the correlation coefficient between them being 0.94). In contrast, the correlation between the weighted variable and the country-specific populations are lower. ${ }^{22}$ After testing down from this general equation in a similar fashion to that explained above, the final equation obtained is presented as Model 2 in Table 2. All variables and elasticities have the expected signs with the Swiss price, Swiss per capita income, foreign per capita income and commuters all significantly different at the $1 \%$ level and the relative price variable significantly different at the $5 \%$ level suggesting that a $1 \%$ decrease in the Swiss gasoline price would result in a reduction in aggregate gasoline sales in the border region of $174 \%$ - almost identical to the average estimate obtained for Model $\mathbb{1}$. Other elasticities are also similar, if not quite so close; the (average) estimated foreign price elasticity being $0.51 \mathrm{in}$ Model $\mathbb{1}$ and 0.47 in Model 2, with the Swiss income elasticity being 175 in Model $1 c$ and 136 in Model 2 and finally the foreign income elasticity being 0.56 in Model $1 c$ and 0.72 in Model2.

In summary, the statistical results for both Model $1 \varepsilon$ and Model 2 are very similar with the estimated key elasticities very similar. In trying to choose whether Model 2 is superior to Model $\mathbb{1}$, conventional tests are not possible given the two models are

\footnotetext{
${ }^{21}$ It should be noted that at first sight the sign of the weighted relative price variable appears incorrect, but this is not the case, since it is the resultant price elasticities given by equations (4) and (5) and presented in Table 2 that are relevant here and these do have the expected signs.

${ }^{22}$ At $0.6,0.8$, and -0.1 respectively.
} 
non-nested. Therefore 'information criteria' were calculated ${ }^{23}$ and the non-nested

Davidson and MacKinoon J Test ${ }^{24}$ conducted and are presented in Table 2. According to both the Akaike and the Schwarz criteria Model $1 c$ is preferred given the lower values for the two measures. Similarly, the J-test suggests that Model $1 c$ is superior given that no added explanatory power is found by adding the fitted values of Model 2 to Model $1 c$, whereas there is additional explanatory power from adding the fitted values from Model $\mathbb{k}$ to Model 2. Hence Model $\mathbb{k}$ is our overall preferred specification with the estimated (average) elasticities with respect to the Swiss price and the foreign price equal to -175 and 0.51 respectively and the estimated elasticities with respect to Swiss income and foreign income equal to 175 and 0.56 respectively. As expected, this elasticity is higher than the Swiss gasoline price elasticities presented in other studies (as discussed in section 2). This is not surprising, given an increase in the Swiss gasoline prices affects not only the Swiss but also the foreign car drivers who have less economic incentives to buy gasoline behind the border. In addition, as expected, the variable for commuters seems to explain some of the fluctuations in gasoline demand in border regions - suggesting that an increase of $\mathbf{1 0 \%}$ in the number of daily commuters to Switzerland increases the demand for gasoline in the border regions by approximately $3 \%$.

\footnotetext{
${ }^{23}$ The TSCS procedure in Limdep 8 does not calculate the Akaike and the Schwarz criteria automatically, therefore these were calculated using the formulae given in Greene (2003, p.160).

${ }^{24}$ The test of Model $1 c$ against Model 2 involves adding the fitted values from Model 2 to Model $1 c$ and testing the null hypothesis that the coefficient on the added fitted variable is equal to zero. If the null hypothesis is not rejected then this indicates that Model $\mathbb{1} c$ is the 'true' model given no additional explanatory power was added from the fitted values from Model 2; Model lc encompasses Model 2. However, if the null hypothesis is rejected this would suggest that Model $1 \mathrm{c}$ is not the 'true' model. To test Model 2 against Model Ic the hypothesis and procedure is reversed; the fitted values from Model $1 \mathrm{c}$ are added to Model 2 and tests the null hypothesis that the coefficient of the additional fitted variable is equal to zero. If the null hypothesis is not rejected then this indicates that Model 2 is the 'true' model given no additional explanatory power was added from the fitted values from Model 1 ; Model 2 encompasses Model $\mathbb{1}$. However, if the null hypothesis is rejected this would suggest that Model 2 is not the 'true' model. (See, for example, Gujarati, 2003, pp.533-536.)
} 


\section{\{Table 2 about here\}}

It has been shown that the estimated price coefficients are robust to the different specifications. This is also true when considering alternative specifications such as the inclusion of a dummy variable for the Italian border region in 1995 and/or regional dummies. It is clear therefore that the estimated price elasticities are robust to different econometric approaches and specifications. Given this, based upon the preferred Model $\mathbb{1}$ in Table 2 , it is possible to calculate two counter-factual approximations:

I. To assess the impact of fuel tourism on the overall gasoline demand over the estimation period in the border regions of Switzerland;

II. To estimate what the effects might have been from the imposition of the proposed $\mathrm{CO}_{2}$-tax on fuel tourism in the border regions of Switzerland.

\section{Counter-Factual Simulation I}

To achieve this, the ratio of the foreign gasoline price to the Swiss gasoline price is set equal to unity (i.e. assuming there is no price difference between the countries) and then, using the other explanatory variables included in Model $\mathbb{1}$ (Table 2), calculate the 'predicted' gasoline demand for each year and border region. ${ }^{25}$ These 'predictions', which reflect the gasoline demand that would have existed without a gasoline price differential between Switzerland and its neighbour countries, are compared with the fitted gasoline demand data given the observed prices. The ratio

\footnotetext{
${ }^{25}$ Implicitly, this asssumes that the foreign price in each region was the same as the Swiss price as opposed to an adjustment in the Swiss price given this would implicitly affect both the tourism and the indigenous fuel demand rather than just the fuel tourism demand.
} 
of the 'predicted' and 'fitted' gasoline demand gives an approximation of the effect of the phenomenon of cross-border fuel tourism and is illustrated in Figure 4.

\section{\{Figure 4 about here\}}

Figure 4 illustrates the development of fuel tourism in the Swiss border regions $5 \mathrm{~km}$ from to border. Over the period 1985 to 1997 fuel tourism is estimated to have accounted for, on average, approximately $9 \%$ of overall gasoline demand in the border regions. From 1985 to 1992, according to our estimates, fuel tourism accounted on average for approximately $\mathbf{1} \%$ of overall gasoline demand in these regions. From 1992 to 1997 , its importance decreased slightly to around $7 \%$. Within this there is some variation between the different regions. In the Italian border region from 1985 until 1992, approximately $2 \%$ of gasoline sales accounted for people coming from abroad. In the same period, the fuel tourism in the border region to Germany was very small and in fact negative between 1985 and 1988, when the Swiss gasoline price exceeded the German price. Cross-border fuelling in the border region to France seemed to be very similar to the Swiss average. Finally, it is worth noting that from 1993 to 1997, the difference between the regions became less important because of the smaller difference in gasoline prices. In summary, this shows that price differentials of homogeneous goods, like gasoline, induce important cross-border movements; consequently, these revenue sources cannot be considered as very stable, since they depend mostly on the foreign fiscal policies. ${ }^{26}$

\footnotetext{
${ }^{26}$ And also on exchange rate fluctuations.
} 


\section{Counter-Factual Simulation II}

Given the argument that the introduction of the proposed Swiss $\mathrm{CO}_{2}$-tax would result in a significant loss in revenue because of the reduction of fuel tourism, Model Ic in Table 2 is also used to simulate the likely effects of introducing the tax on fuel tourism. To construct this simulation, the 'predicted' values from imposing a hypothetical $\mathrm{CO}_{2}$-tax and eliminating the cross border price differential by adjusting the foreign price is compared to the 'predicted' values from just imposing the hypothetical tax. The ratio of these, illustrated in Figure 5, gives an approximate indication of fuel tourism if such a tax were imposed.

\section{\{Figure 5 about here\}}

Figure 5 illustrates an overall reduction in fuel tourism for every year. At the start of the estimation period, 1985, estimated overall fuel tourism accounted for about $6 \%$ but is reduced to just above $0 \%$ following the imposition of the hypothetical tax and at the peak of fuel tourism in 1992 it falls from of $16 \%$ to about $9 \%$. Furthermore, in the period after 1992 when fuel tourism declines, the share of fuel tourism decreases by approximately $6 \%$ (from $7 \%$ to around $1 \%$ ), given the price differences, which were much smaller (or negative) than in the earlier period. It is also interesting to focus on the figures for 1997, where the gasoline price differential between the Swiss price and the border regions was on average 30 Swiss Cents so that the introduction of the hypothetical tax results in the average price differential being considerably reduced; consequently simulated total fuel tourism to Switzerland reduces significantly to around $3 \%$ of fuel demand in the border area. ${ }^{27}$ This is

\footnotetext{
${ }^{27}$ Within this fuel tourism from Italy and France is still positive, but is negative for Germany.
} 
particularly pertinent given that the price differential at the beginning of 2005 was about 32 Swiss Cents so that the introduction of the $\mathrm{CO}_{2}$-tax is likely to have a similar effect with the important reduction of fuel tourism with the resultant reduction in fiscal revenue and employment. Moreover, although this would also reduce $\mathrm{CO}_{2}$ emissions emanating from gasoline purchased in the Swiss border regions, the global effect is likely to be somewhat less given the fuel tourism component is likely to be transferred to the neighbouring border regions. However, despite this, there are positive effects such as less congestion and less local pollution. For instance, the reduced fuel tourism would go someway way in reducing the severe air pollution problem in the border region with Italy.

\section{Summary and Conclusion}

This paper explores the issue of 'Fuel Tourism' in Switzerland. Using a panel data set for the three regions of Switzerland bordering Italy, Germany, and France, over the period 1985 - 1997 it is shown that there is a significant impact of the gasoline price differential on fuel demand. The estimated price elasticities suggest that a decrease of $10 \%$ in the Swiss gasoline price will lead to an increase in demand of by about 17.1/2\%. Moreover, the estimated equation is utilised to simulate the effect of fuel tourism on gasoline demand in the border regions and the introduction of the proposed $\mathrm{CO}_{2}$-tax. The first simulation indicates that from 1985 to 1997 estimated fuel tourism accounted for about $9 \%$ of overall gasoline sales on average; whereas the second indicates that if a hypothetical $\mathrm{CO}_{2}$-tax were introduced it would have reduced fuel tourism in the three border regions significantly. 
From an energy policy perspective, a unilateral policy, such as the proposed $\mathrm{CO}_{2}$-tax, aimed at discouraging gasoline consumption in the border regions for environmental reasons is unlikely to be effective both in terms of revenue and the global environmental impact, although there may well be local advantages from less congestion and pollution. Whereas, policies to counter the negative side-effects of fuel tourism, like those introduced in Italy, would appear to be reasonably successful in avoiding a loss of taxes as well as losses for owners of gas stations in the border region with higher taxes. In Switzerland, this implies that there might be a need to restructure the fuel-selling sector in the border regions. Therefore, the benefits of additional working places and revenues generated by fuel tourism have to be compared to the external environmental and health costs involved in the border region 


\section{References}

Beard, T. R, Gant, P. A., Saba, R. P. 1997. Border-Crossing Sales, Tax Avoidance, and State Tax Policies: An Application to Alcohol, Southern Economic Journal, Vol. 64, No. 1, July, pp. 293-306.

Becker, G.S., 1965. A Theory of the Allocation of Time, Economic Journal, Vol. 75, No. 299, September, pp. 493-517.

Bundesgesetz vom 8. Oktober 1999 zur Reduktion der CO2-Emissionen (CO2-Gesetz)

Coats, R. M., 1995. A note on estimating cross-border effects of state cigarettetaxes, National Tax Journal, Vol. 48, No. 4, December, pp. 573-584.

Credit Suisse, 2000. II Ticino e le Regioni dell'Italia del Nord-Struttura e prospettive economiche, Economic Research - Analisi regionali, October.

Deaton, A., Muellbauer, J., 1980. Economics and Consumer Behaviour, Cambridge University Press, Cambridge, UK.

Di Matteo, L, Di Matteo, R., 1996. An Analysis of Canadian Cross-Border Travel, Annals of Tourism Research, Vol. 23, No. 1, pp. 103-122.

Garrett, T. A., Marsh, T. L, 2002. The revenue impacts of cross-border lottery shopping in the presence of spatial autocorrelation, Regional Science and Urban Economics, Vol. 32, pp. 501519.

Greene, W. H., 2003. Econometric Analysis (5 ${ }^{\text {th }}$ Edition), Prentice Hall, New Jersey.

Greene, W. H., 2002, Limdep Version 8.0 -Econometric Modeling Guide, Econometric Software, Inc., Plainview, NY, USAVCastle Hill, NSW, Australia.

Gujarati, D. N., 2003. Basic Econometrics (4 ${ }^{\text {th }}$ Edition), McGraw-Hill, New York International Energy Agency, 1999, Energy Policies of the IEA Countries- Switzerland 1999 Review, OECD, Paris.

Kmenta, J., 1986. Elements of Econometrics, Macmillian Publishing Company, New York.

Lilley III, W., DeFranco, L J., 1996. Impact of Retail Taxes on the Illinois-Indiana Border, paper presented at the workshop “Designing State-Local Fiscal Policy for Growth and Development", Federal Reserve Bank, Chicago.

Lin, A.-I., Botsas, E. N., Monroe, S. A., 1985. State gasoline consumption in the USAAn econometric analysis, Energy Economics, Vol. 7, No. 1, January, pp. 29-36.

Merrifield, D. E., Storer, P., 1999. Cross-Border Shopping and Economics Activity in Whatcom County, Washington: Gasoline ServiceStations 1988-98, paper presented at the Pacific Northwest Regional Economic Conference, Boise Idaho, April.

Michaelis, P., 2003. Tanktourismus - eine Szenario-Analyse, Volkswirtschaftliche Diskussionsreihe, Institut für Volkswirtschaftslehre, Beitrag Nr. 249, September, Universität Augsburg. 
Muth, R.F., 1966. Household production and consumer demand functions, Econometrica, Vol. 34, pp. 699-709.

Pesaran, H., Smith, R. P., Akiyama, T., 1998. Energy Demand in Asian Developing Economies. Oxford UniversityPress, Oxford, UK.

Rietveld, P., Bruinsma, F.R, van Vuuren, D.J., 2001 Spatial graduation of fuel taxes; consequences for cross-border and domestic fuelling, Transportation Research Part A, Vol. 35, pp. 433-457.

Saba, R. P., Beard, T.R., Ekelund, R. B, Ressler, R. W., 1995. The Demand for Cigarette Smuggling, Economic Inquiry, Vol. 33, No. 2, April, pp 189-202.

Schleiniger, R, 1995. The demand for gasoline in Switzerland - in the Short and in the Long Run, Discussion paper 9503, Institute for Empirical Research in Economics, University of Zurich, Zurich.

Wasserfallen, W., Güntensperger, H., 1988. Gasoline consumption and the stock of motor vehicle- An empirical analysis for the Swiss economy, Energy Economics, October, pp. 276-282. 


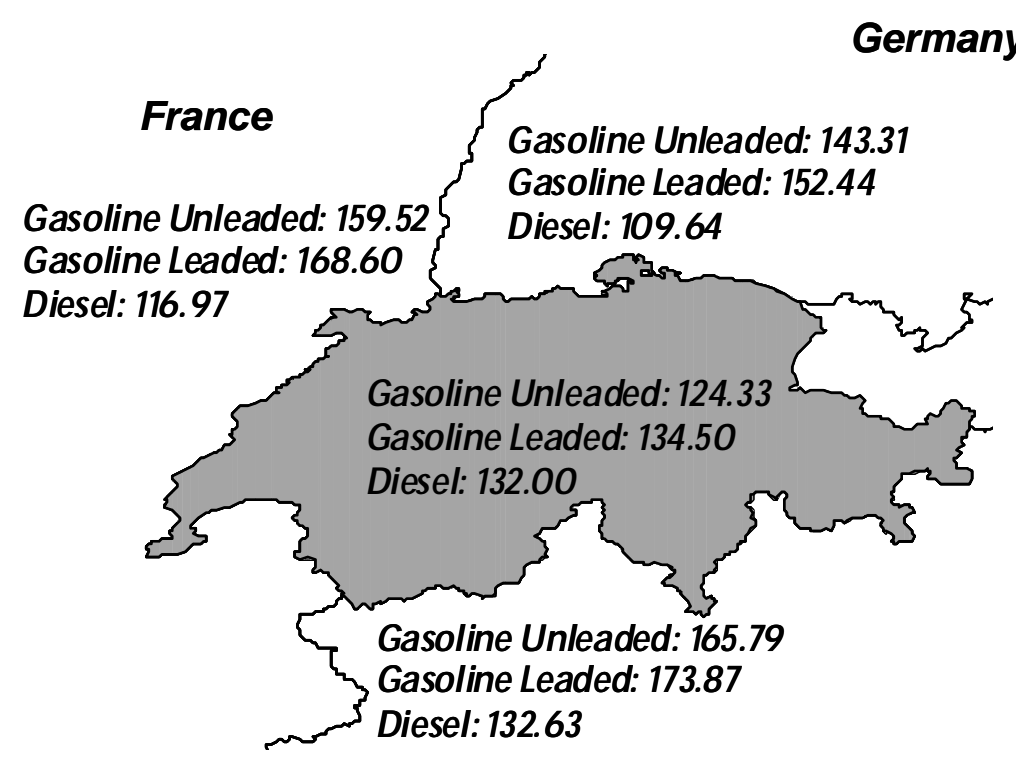

Italy

Fig. 1 Gasoline (leaded and unleaded) and diesel prices in the year 1997 for Switzerland and its neighbouring countries, in Swiss Cents ( $1 €=148$ CHF) 


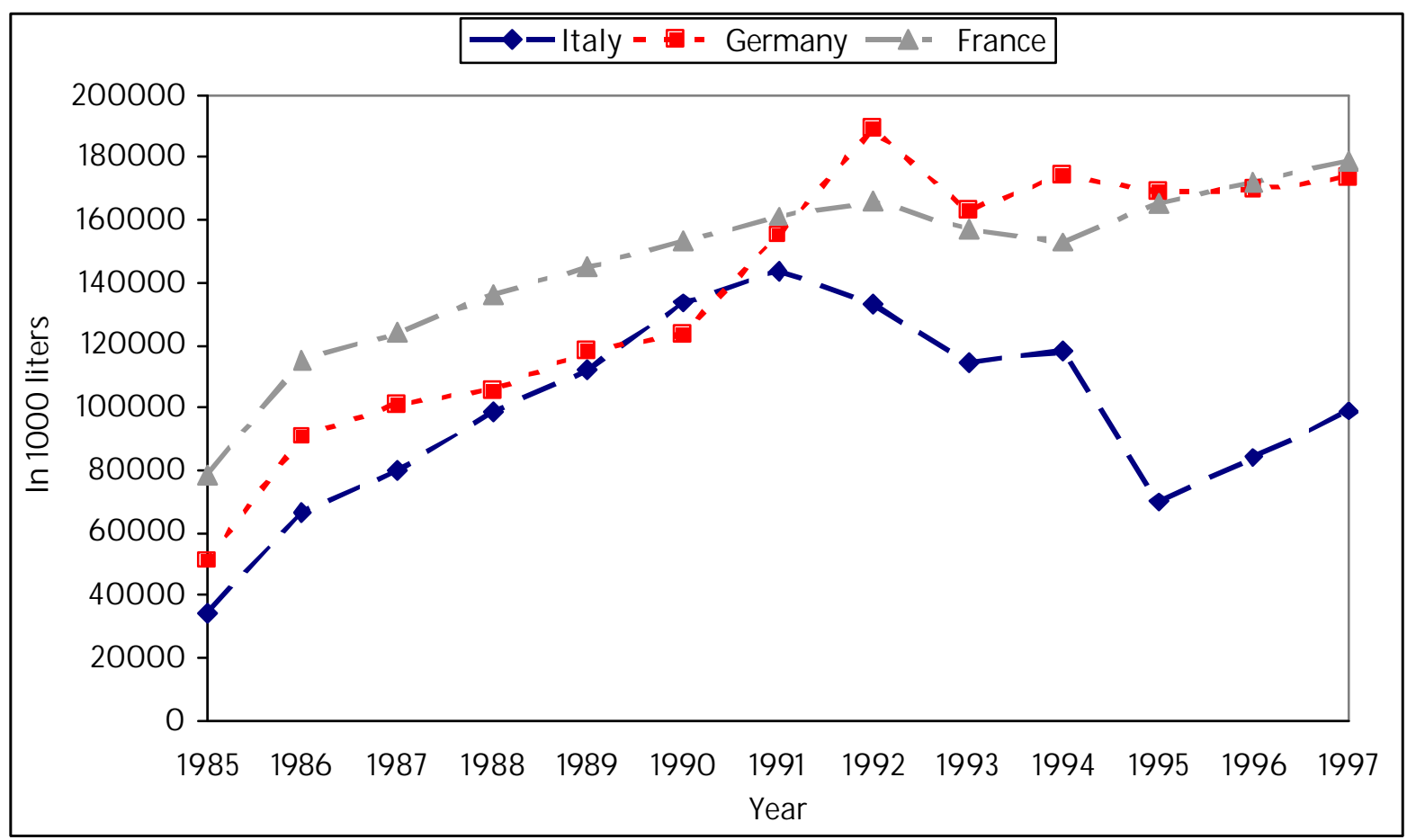

Fig. 2. Development of gasoline demand of the three main companies in the border regions of Switzerland for the years 1985 to 1997 


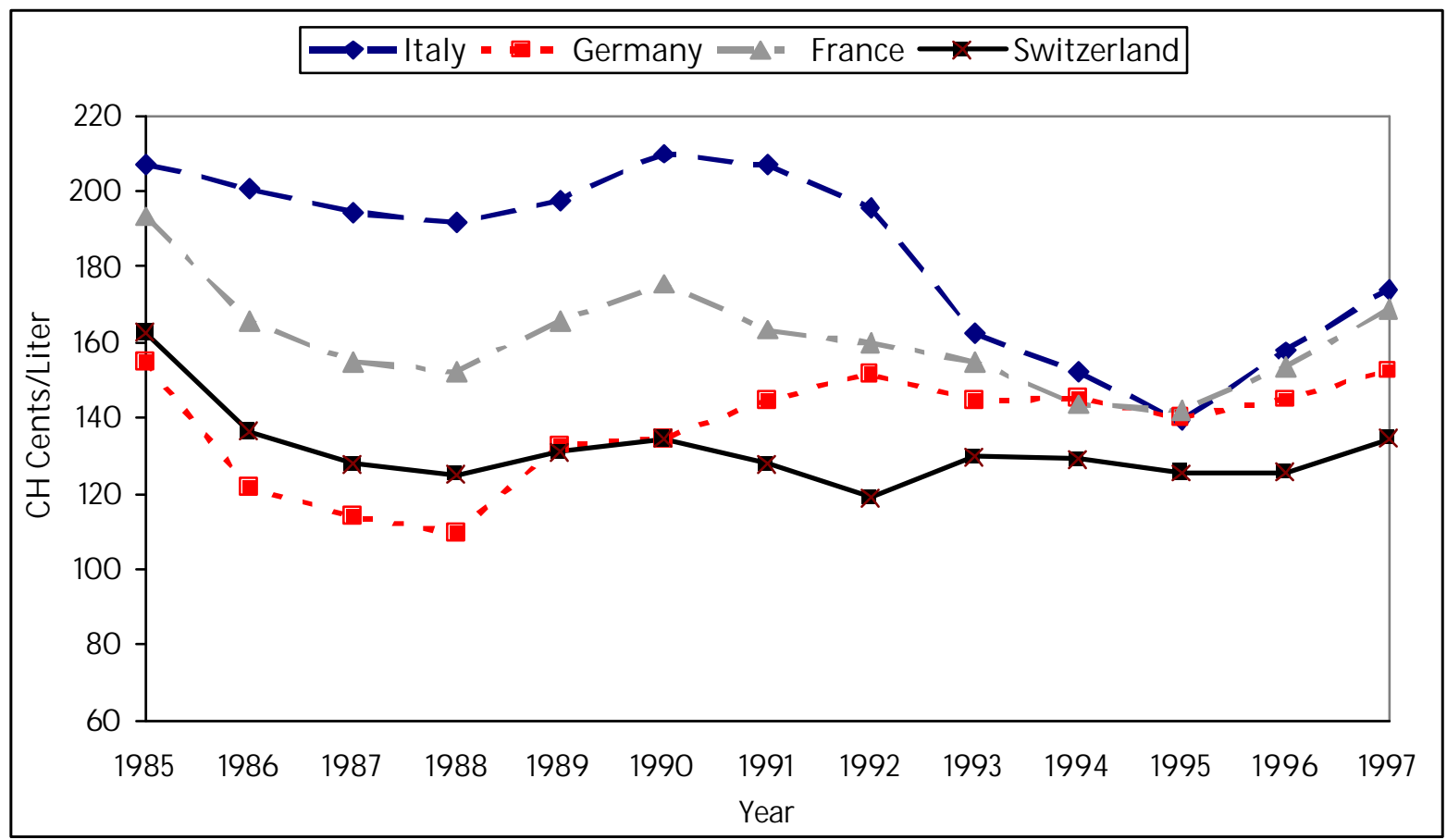

Fig. 3. Development of the price of leaded gasoline (in Swiss Cents/litre) between 1985 and 1997 


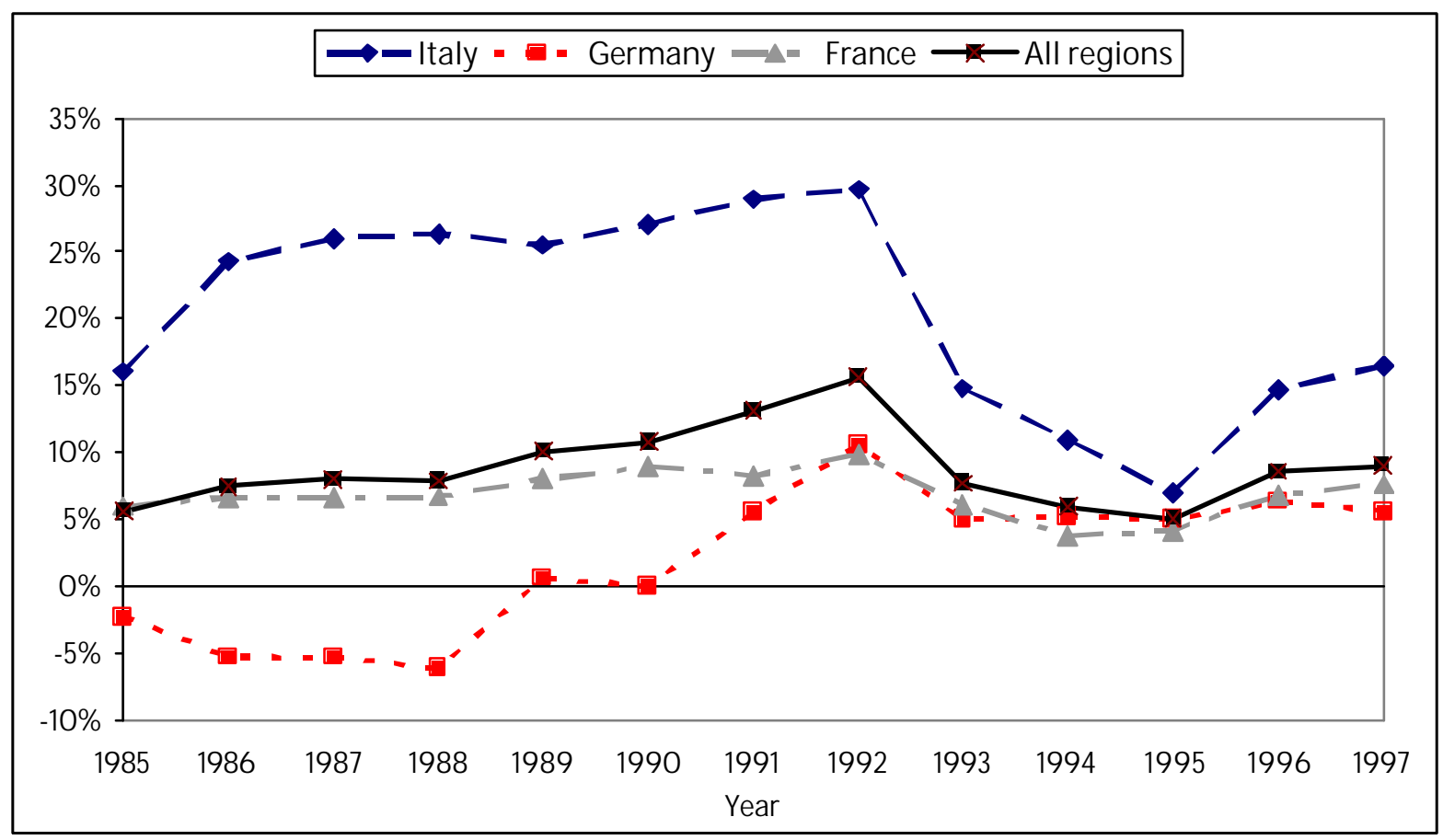

Fig. 4. Counter-Factual Simulation I: 'Fuel tourism' as a percent of total gasoline demand in the border regions between 1985 and 1997 


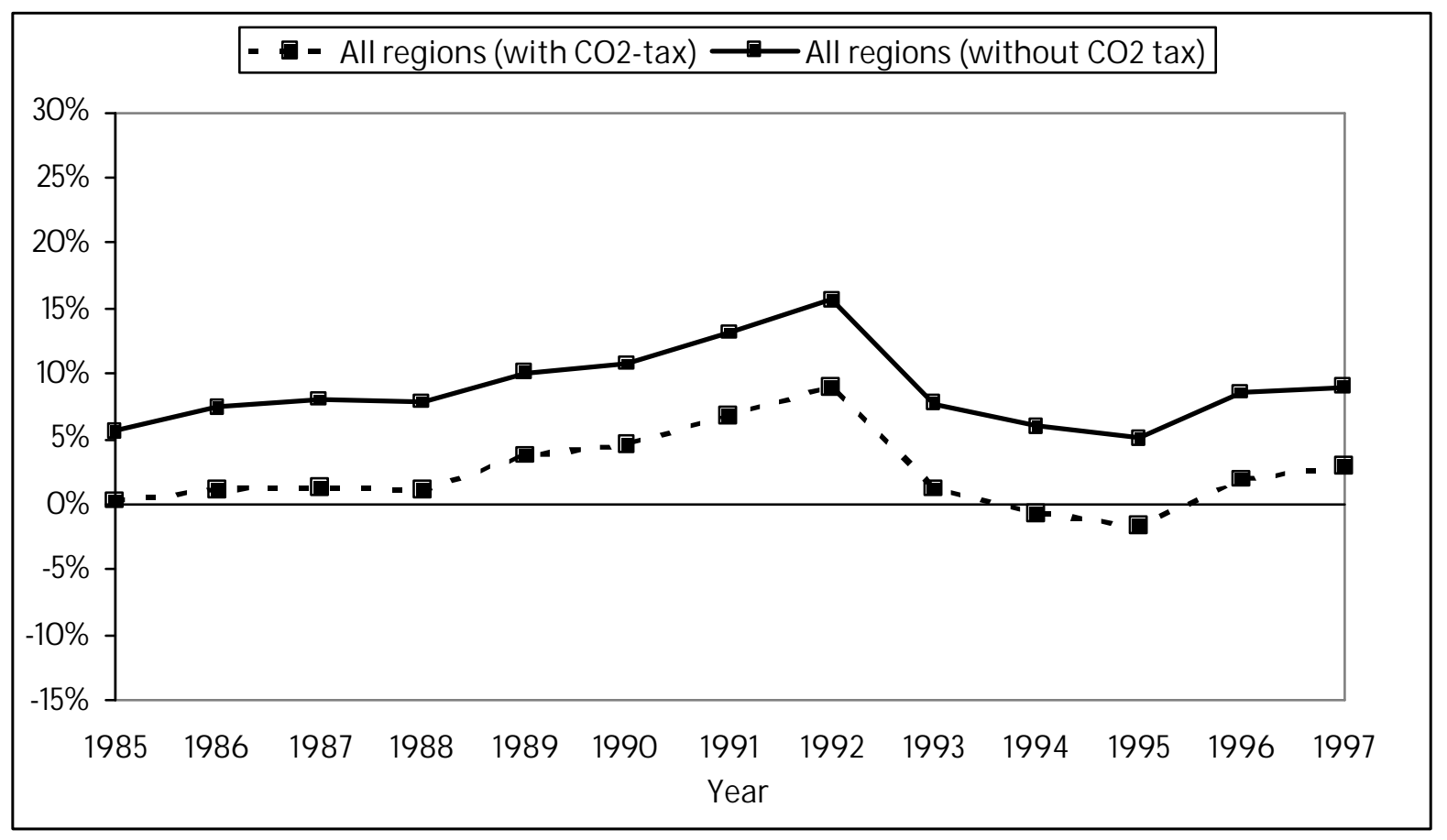

Fig. 5. Counter-factual simulation II: 'Fuel tourism' as a percent of total gasoline demand in the border regions between 1985 and 1997 after the introduction of a hypothetical $\mathrm{CO}_{2}$-tax of 20 Swiss Cents. 
Table 1

Description of data

\begin{tabular}{|c|c|c|c|c|}
\hline Variable & Measure & Min. & Max. & Median \\
\hline \multicolumn{5}{|l|}{ Gasoline demand } \\
\hline Border region to Italy & 1000 litres/y & $34^{\prime} 471$ & $143^{\prime} 721$ & 98'994 \\
\hline Border region to Germany & 1000 litres/y & 51'131 & 189'136 & 155'181 \\
\hline Border region to France & 1000 litres/y & $78^{\prime} 698$ & $1799^{\prime} 062$ & $153 \prime 350$ \\
\hline \multicolumn{5}{|l|}{ Gasoline price } \\
\hline Switzerland & $\mathrm{CHF} / \mathrm{I}$ & 179 & 163 & 129 \\
\hline Italy & $\mathrm{CHF} / \mathrm{I}$ & 139 & 2.10 & 194 \\
\hline Germany & $\mathrm{CHF} / \mathrm{I}$ & 110 & 155 & 145 \\
\hline France & $\mathrm{CHF} / \mathrm{I}$ & 142 & 193 & 160 \\
\hline \multicolumn{5}{|l|}{$\begin{array}{l}\text { Swiss per capita regional } \\
\text { income }\end{array}$} \\
\hline Border regional to Italy & $\mathrm{CHF} / \mathrm{y}$ & $35 ’ 935$ & $41^{\prime} 557$ & $40 \prime 275$ \\
\hline Border regional to Germany & $\mathrm{CHF} / \mathrm{y}$ & $47^{\prime} 473$ & $55^{\prime} 504$ & $52^{\prime} 568$ \\
\hline Border regional to France & $\mathrm{CHF} / \mathrm{y}$ & $46 \prime 561$ & $54^{\prime} 207$ & $49 \prime 945$ \\
\hline \multicolumn{5}{|l|}{ Foreign per capita income } \\
\hline Italian regional income & $\mathrm{CHF} / \mathrm{y}$ & 17798 & $37^{\prime} 541$ & 27942 \\
\hline German regional income & $\mathrm{CHF} / \mathrm{y}$ & $25^{\prime} 867$ & $41^{\prime} 055$ & $34^{\prime} 774$ \\
\hline French regional income & $\mathrm{CHF} / \mathrm{y}$ & 22,246 & $33^{\prime} 267$ & 28 '9D \\
\hline \multicolumn{5}{|l|}{ Commuters } \\
\hline From Italy & Persons/y & $18 ' 876$ & $44^{\prime} 476$ & $38^{\prime} 486$ \\
\hline From Germany & Persons/y & $18^{\prime} 876$ & $377^{\prime} 493$ & $31^{\prime} 469$ \\
\hline From France & Persons/y & $49^{\prime} 526$ & $84^{\prime} 557$ & $74^{\prime} 005$ \\
\hline \multicolumn{5}{|l|}{ Regional population } \\
\hline Switzerland - Italy & Persons & $9^{\prime} 1188^{\prime} 425$ & 9'279'388 & 9'173'330 \\
\hline Switzerland - Germany & Persons & $22^{\prime} 489 \prime 075$ & $24^{\prime} 906^{\prime} 736$ & $23^{\prime} 795^{\prime} 115$ \\
\hline Switzerland - France & Persons & 7'352'878 & 7'949'127 & $7^{\prime} 709^{\prime} 970$ \\
\hline \multicolumn{5}{|l|}{ Stock of Cars } \\
\hline Switzerland - Italy & $\begin{array}{l}\text { Cars/ } 1000 \\
\text { Persons }\end{array}$ & 454 & 573 & 535 \\
\hline Switzerland - Germany & $\begin{array}{l}\text { Cars/ } 1000 \\
\text { Persons }\end{array}$ & 358 & 398 & 381 \\
\hline Switzerland - France & $\begin{array}{l}\text { Cars/ } 1000 \\
\text { Persons }\end{array}$ & 458 & 507 & 496 \\
\hline
\end{tabular}


Table2

Estimated Equations: dependent variable: $\mathrm{G}$ (gasoline demand in the border region)

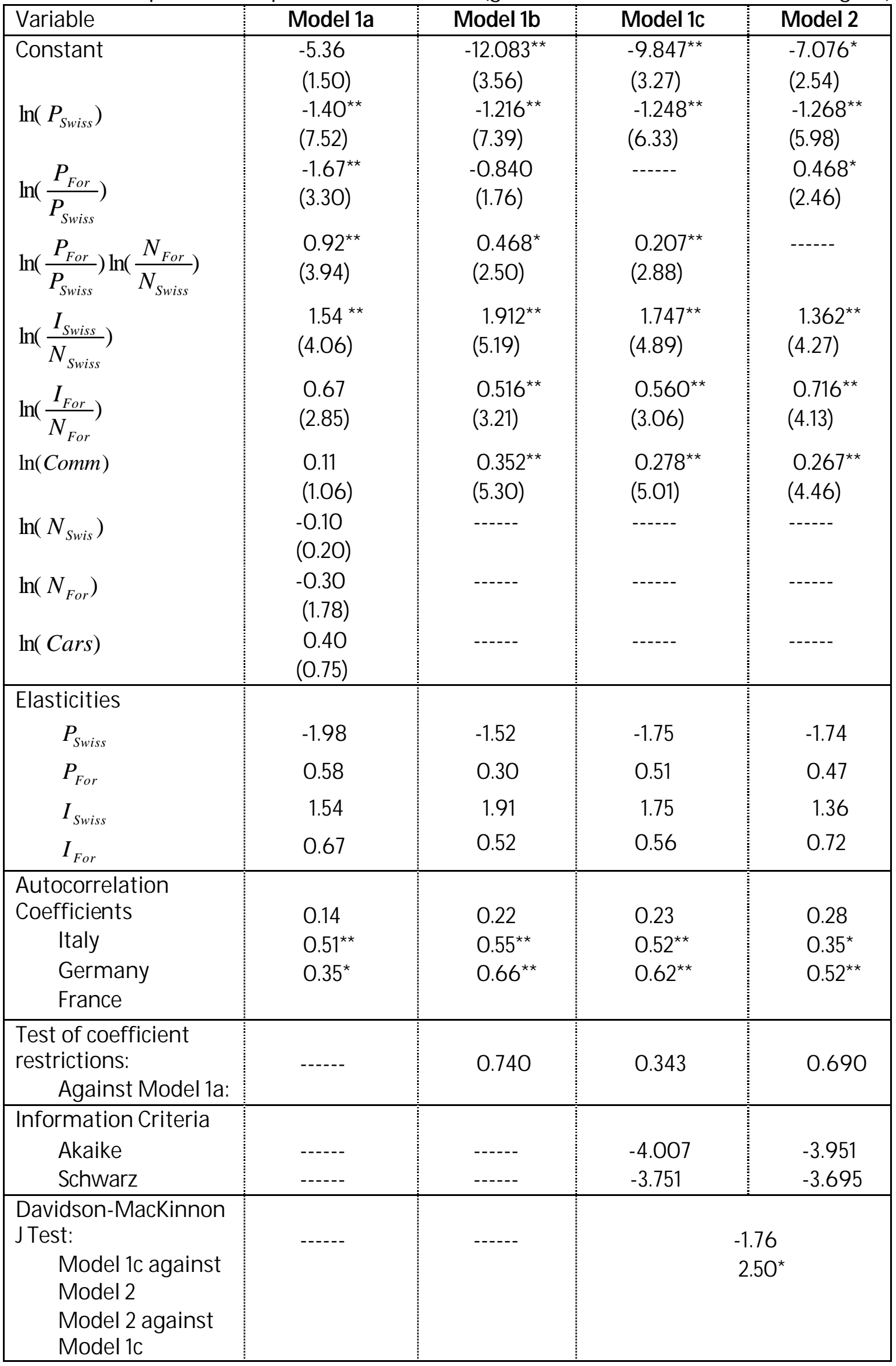


Notes:

- Number of observations: 39 (13 for each border region)

- $\quad$ All models estimated by 2-step GLS with adjustment for country specific autocorrelation and country-wise heteroscedasticity

- $\quad \mathrm{t}$-statistics are in parenthesis

- * * and *. coefficients are significantly different from zero at the $1 \%$ and $5 \%$ levels respectively.

- Price elasticities for Models $\mathrm{la}, \mathrm{lb}$, and $\mathrm{lc}$ are evaluated at the variable means according to equations (4) and (5).

- The test of restrictions against Model la is the standard F test with 3 and 29 degrees of freedom for Model $\mathrm{lb}$ and 4 and 29 degrees of freedom for Model $1 c$ and Model 2.

- The Davidson-MacKinnon J Test is distributed as a student t-distribution with 32 degrees of freedom. 